\title{
The Gaols of Guyana: Hauntology and Trauma in the soundscape of Prison ${ }^{1}$
}

\author{
Tammy C. Ayres ${ }^{2}$ and Dylan Kerrigan ${ }^{3}$
}

\begin{abstract}
Using Hauntology, this paper illustrates how the supposed demise of a socio-political and economic system - colonialism - still impacts on and has something to offer contemporary political analysis in Guyana's gaols. Drawing on Fiddler's spatio-hauntology alongside the work of Derrida and Gordon this paper shows how hauntology provides an alternative theoretical framework to look at the intergenerational transmission of trauma, which can be traced back to colonialism and slavery. It acknowledges the impact structural violence has on the collective imaginary and how this - consciously and unconsciously - shapes the psychosocial material underpinning contemporary Guyanese identities, desires, experiences, social action, and systems of punishment which includes prisons - its buildings, space, regimes, processes, sounds, laws and rationale. Guyana's prisons contain phantoms of the past. Only by acknowledging Guyana's ghosts and the phantasm of past trauma is it that we can begin to understand contemporary Guyana and Guyanese society, which includes their jails.
\end{abstract}

Keywords: Prisons, Sound, Hauntology, Guyana, Trauma

Standing at the side of the road of what seems like a quiet residential area, the surrounding wall - made out of corrugated iron and painted in a deep blood red - hides the prison from sight, bar a white/cream wooden building with peeling paint peeking out over the top. Inside, the wooden clad buildings are painted white with red rooves, like chalets on a beach, but much bigger and more imposing... Once inside the wooden and concrete structure is eerily reminiscent of old Victorian buildings you would expect to see in a museum or on a heritage site rather than in a modern-day, working, prison...The rickety and damaged wooden structures that dominate the space, alongside the large metal doors (some of which are rusting and battered) and thick bars crossing the tiny, almost pointless, windows are indicative of a prison, a prison in Guyana. A prison of yester-year. Prisons at the turn of the 19th Century. It is, like stepping back in time, even though we are not, and in reality, this is very much the twenty-first Century, you cannot escape the stories, memories and feelings trapped in the space as we move around quietly and cautiously. (Field note from visit to New Amsterdam prison established under Dutch colonial rule in 1814).

\footnotetext{
1 This paper is based on research conducted for the ESRC-funded project Mental Health, Neurological and Substance Abuse (MNS) Disorders in Guyana's Jails: 1825 to the present day (award no. ES/S000569/1). This project is a collaboration between the University of Guyana and the University of Leicester, in partnership with the Guyana Prison Service. The project brings into dialogue researchers in History, Criminology, Sociology and Literature. It takes both a multi-disciplinary and interdisciplinary approach to key questions about the form, function, and experience of incarceration, encompassing inmates and the people who work with them. It encompasses both the British colonial period, and the era since Guyana's independence in 1966.

${ }^{2}$ Associate Professor, Department of Criminology, University of Leicester, Leicester, UK. Email: tca2@le.ac.uk. ORCID: 0000-0002-2590-9558.

${ }^{3}$ Lecturer, Department of Criminology, University of Leicester, Leicester, UK. Email: dk252@1e.ac.uk. ORCID: 0000-0003-2453-9804.
} 


\section{Introduction: Haunting Sounds}

This paper draws on interdisciplinary research that crosses sociology, (critical) criminology, history, philosophy, and emotional and auditory geography, to draw on the philosophical concept of hauntology. Hauntology explains how the present only exists because of the past, which plagues it like a spectre/ghost that can be present or absent. Thus hauntology 'draws us affectively, sometimes against our will and always a bit magically, into the structure of feeling of a reality we come to experience, not as cold knowledge, but as a transformative recognition' (Gordon, 1997: 8). Hauntology provides us with an alternative way of knowing and understanding, not only about 'what has happened but what is happening now' (Gordon, 1997: 8). Drawing on Michael Fiddler's (2019) work on spatio-hauntology alongside the work of Derrida (1994) and Gordon (1997), it provides a conceptual and theoretical background to research currently being undertaken in Guyana's prisons, including the development of a Public Address system for rehabilitative work with prisoners and staff as a means of delivering training and education. Prisons that are haunted by past traumas, traumas that have intergenerational consequences; and that we hypothesis and illustrate may underpin some MNS disorders in Guyana's Prisons today ${ }^{4}$. It is in this context that the ghosts haunting Guyana's gaols in soundscapes, in infrastructure and in the narratives of prisoners are able to help us see echoes of the past in the present and fill some of the silences and absences that connect the two (de Sousa Santos 2015).

\section{Hauntology: Ghosts of the Past}

The ghosts of Guyana's past cannot be ignored. They left echoes. Built on colonial sugar production, enslavement, and exploitation, and despite independence, the remnants of colonial rule in Guyana are still evident today. Both Guyana's colonial-era and post-colonial jails retain many of the old processes and regimes implemented during colonial times. Prisons and penal colonies across the British Empire sustained and built imperial economies, and British penal policy must be seen as part of the social and cultural fabric of these colonised countries as well as being integral to the establishment of global capitalism (Anderson, 2016; Grosfoguel, 2007; Quijano, 2000). Historically prisons are symbolic of the building and binding of Empire through coercion and social control. However, today, not only are the ghosts of coloniality disavowed, but the relationship between the hierarchies and structures of colonialism, and the development and social classes of racialised capitalism are also made invisible and become a ghostly presence haunting the globe (Robinson 1981). Hauntology illustrates how the supposed demise of a socio-political system - colonialism - still impacts on and has something to offer contemporary political analysis. Though, as colonial amnesia and social forgetting dominate, hauntology allows us to fill the silences of such amnesia and look beyond official discourse to what is missing and absent. Whether that relates to archives and record keeping (Anderson 2012), the secrets and facts omitted from official discourse and culture (e.g., literature, poems, art and music), and/or people's memories. Filling such silences contributes to the partial liberation of collective imaginary, which has been shaped by place and space (Stoler, 2006). This includes prisons and their violent histories rife with trauma.

Violent histories and their resultant traumas 'not only haunt the actual victims, but are also passed on through generations' (Schwab, 2010: I). Thus, hauntology provides an alternative theoretical framework to look at the intergenerational transmission of trauma that can be traced back to colonialism and slavery and the shift to the public management of punishment after emancipation. The intergenerational transmission of trauma 'from the past to

\footnotetext{
${ }^{4}$ An ESRC-funded project Mental Health, Neurological and Substance Abuse (MNS) Disorders in Guyana's Jails: 1825 to the present day (award no. ES/S000569/1). This project is a collaboration between the University of Guyana and the University of Leicester, in partnership with the Guyana Prison Service.
} 
the present, from one generation to another, and from one person to another' (Frosh, 2013: 118), acknowledges the impact structural violence has on the collective imaginary and how this - consciously and unconsciously - shapes the psychosocial material underpinning contemporary Guyanese identities, desires, experiences and social action.

These traumatic spectres intergenerationally haunt both the staff and prisoners in the contemporary Guyanese prison. For example, in Guyana's prisons the role of religion and in particular evangelical Christianity to both inmates and prison staff in the context of ideas and cosmologies around punishment and morality is a strong connection from colonialism to the present. Family histories are also important as many of the frontline staff we have been working with have followed previous family members into the prison service. While the 2017 national survey of inmates in Guyana's prisons noted that four out of ten inmates said they had a family member who had been previously sent to prison (Sarsfield and Bergman, 2017). Both religion and family histories haunt both the infrastructure and lives of those that make up Guyana's prison, but they also provide coping mechanisms in uneven ways for the trauma of prison life including its impact on mental health (Clarke 2010: 111). Hauntology not only facilitates the understanding of these colonial afterlives, but also how colonialism has and continues to structure the world around us, which includes foundations of knowing and forgetting (Gregory, 2004; Quijano 2000; Said, 1978).

\section{Spatio-Hauntology and Ghosts of Guyana's Gaols}

The gaols in Guyana contain 'spatial traces of trauma', which according to Fiddler (2019: 7), are places where 'the trauma of both historical and contemporary violence come together in the same space'. The collective memory of gaols generally, and in Guyana specifically, are haunted by the 'ghosts of past violence' (Linnemann, 2015). Whether that is captured in stories, folklore, art, poetry, song, prison structures or spaces, the ghosts of the past haunt the present (Carter, 1979; Childs, 2015; De Ferrari, 2018; Gampat, 2015; Harris, 1993, 1996, 2006). This has been well outlined in the allegorical work of Wilson Harris (cited in Bundy, 1999: 170):

Such a quest invites us to look afresh in each age at the life of the imagination, as this addresses us from the past with a new intuitive logic and design that diverges from the prison of the past, or which speaks through us towards the past and the future in a manner that also subtly diverges from the prison of the present, and ... from popular prejudice.

Using Fiddler's (2019) spatio-hauntology, prisons in Guyana can be described as spatial crypts, containing the phantom of traumatic events from the past and its surrounding locale that is suffused by colonial occupation, indigenous displacement, coerced labour, the plantation economy and their accompanying violence and trauma. In fact, not only did the British continue to use Dutch prisons after occupation in 1815, following Independence in 1966, one of Guyana's prisons (Lusignan) was built on the grounds of a former plantation hospital. Anderson and colleagues (2020) also make the point that prisons in Guyana were used to contain 'lunatics' and there was mobility between the asylum and prisons. These points illustrate how in some places and spaces there is 'a layering of social violences to create a collective burial ground ... a space in distress' (Fiddler, 2019: 473).

Guyana's prisons are certainly spaces in distress - as the present conditions of their crumbling infrastructures illustrate. In Guyana these spaces of distress are not simply metaphors for prison regimes; decay is literally the case. Symbolic and material manifestations of colonial rule - in some of the prisons the spaces themselves are colonial era and in others 
the cultural memories are in new prisons. Guyana's prisons are cultural spaces that entomb cultural memories from the past that incorporate a collective exposure to violence and trauma, which has been transmitted through visceral registries ${ }^{5}$ (see Coddington and Micieli-Voutsinas, 2017). As a symbolic institution they embody 'a spatialized history of violence, a violent colonization of a collective and spatialized psyche' (Fiddler, 2019: 471), constitutive of wounded spaces. Prisons today, as colonial slavery and the plantation economy once also did, capture bodies and enslave peoples' time. Guyana's prisons have held 'incarcerated bodies from across multitudinous spaces and times of imprisonment' that 'can be thought as dislodged from their historical locations and gathered together, as ghosts' (D'Harlingue, 2010: 134). The prison - its buildings, space, regimes, processes, sounds, laws and rationale - contain phantoms of the past and are haunted by ghosts of chattel slavery (Childs, 2015; Rodriguez, 2006).

Prisons, like the plantation, constitute states of exception (Agamben, 2005) that create and contain bodies seen as 'non-humans', as both the prisoner and the enslaved are dehumanised or what Salah-Hanna (2015) calls 'animalized'. Prisoners, like those enslaved lay outside the political realm; reduced to Agambean bare life (Agamben, 1995). Plantations like prisons are spaces of violence and forced labour, which is deemed to operate in the service of civilization (Agamben, 2005). Forced to work on the plantations and beaten savagely by their masters, not much was different once they entered prison. Yet at the same time, as Buntman (2019) argues, prisons are not states of exception at all. Following Emancipation prisons in Guyana expanded and they became an alternative means of unfree labour supply, containing and putting to work Indigenous peoples, the formerly enslaved, apprentices, and later indentured labour. As Cameron and Kerrigan remark in this special issue, in social class terms it is the descendants of these same groups who on the whole are captured by prisons in Guyana today.

Prisoners were forced to work, whether that was fieldwork on the estates surrounding the prisons or partaking in some form of punitive or productive labour within the prison. Such labour was enforced by coercive measures (Anderson, Ifill, Adams and Moss, 2020). In similar ways to the enslaved on plantations, prisoners are disposable manual labour; an integral component of capitalism and the global capitalist coloniality of power (Quijano, 2000). In Guyana the violent plantation regime - including its forms of discipline and punishment - was transferred to prisons. Punishment was often tied to labour and production, and thus capitalism (Smith, 2014). It was also tied to ways of knowing, a regimented monopoly over race/ethnicity, criminality and thus difference to create racialised regimes of truth (Grosfoguel, 2007; SalahHanna, 2015; Stoler, 2006, 2008; Quijano, 2000; Anderson et al. 2020). However, these continuities, shifts and connections can be disavowed by colonial amnesia (Trouillot 2003), and as Salah-Hanna (2015: 6) highlights the 'Prison-Industrial-Complex' today constitutes a form of 'modern day slavery'. Therefore, the brutality and barbarity of Caribbean prisons not only represent 'constellations of power' (Fiddler, 2019) but a form of death; civil/social death (Agamben, 1995; Rodriguez, 2006). Prisoners become the living dead, as imprisonment today carries the ghosts of slavery. Imprisonment in spaces of distress and decay - constitutes a living death - a death so slow, no one really notices, particularly as the deaths of prisoners and/or the enslaved do not really count, but occur far too frequently.

The criminalisation and imprisonment of colonised populations has been central to the expansion and maintenance of British colonialism that involves the ownership and regulation

\footnotetext{
${ }^{5}$ Visceral registries and drives refer to it being emotional and experienced as coming from within the body, which is instinctive, unreasonable and comes from a psychological need (hunger, thirst, pain). There is often no rational explanation as visceral feelings are intuitive and difficult to control.
} 
of bodies considered 'other' by the intersecting gazes of Western knowledge and its laws. However, we must also acknowledge the sound of imprisonment and punitive control in this hauntology as the aurality of prisons cannot be ignored and this approach is what we do next in this working paper. The role of sound is not only integral to our understanding of punishment and control, but the carceral soundscape actively reflects and shapes the broader political, economic, social and cultural contexts (Hemsworth, 2015; Wener, 2012).

\section{Prison: Sound, Control and Punishment}

Prisons are rife with unresolved trauma, violence, and suffering, not just in Guyana, but across the globe, which is not only entombed in the architecture, regime and symbolism of prison, but also in the sonic documentation of punitive control and violence entombed within its walls (Middlebrook, 2016). If prisons 'are alive with ghosts of the dead' (Linnemann, 2015: 530) sounds of the past also echo within their walls. As spatial systems characterised by practices that control, structure and dictate the activities of prisoners and staff, prisons are symbolic of the State, and thus contain within them colonial power and control (Rodriguez, 2006). These are largely organised and articulated around sound. Selected sounds permeate both the contemporary and the historical prison, constituting a haunting cacophony of noise. However, the sound of imprisonment is not just a 'sonic documentation of control and violence' or the sound of suffering, but also about the sound of survival and resilience as prisoners will do anything to escape - albeit momentarily - from the dehumanising systems of carceral violence (Childs, 2015; Middlebrook, 2016). Although, sound is embodied in the various pains of imprisonment, it can also be used to alleviate and defy the pains of imprisonment (Sykes, 1958) by providing a sonic escape.

Throughout history sound has been used to surveil, control and punish. From Bentham's panopticon and experiments in regimes of separation and silence, to today's 'panaudio-con' of modern-day alarms, gate buzzers, and PA systems (Hemsworth, 2015); sound is an integral component in the history of punishment. However, aurality is often ignored, despite the soundscape of prison being an integral component of punishment and control. It also has the ability to negatively impact prisoners, undermining their physical and mental wellbeing (Hemsworth, 2015).

In fact, aurality facilitates a better understanding of the production of carceral space its histories, materialities and the trauma-damage it produces. Although sound can be heard to challenge the exclusionary spatial ordering of the prison, it is also fundamental to its spatial ordering and control. Thus, sound operates in three ways: the sound of control, the sound of suffering, and the sound of the imprisoned. In regard to the latter, although it is widely acknowledged that prisoners are a 'captive audience' to the sonic environment in which they are held (Jewkes 2007), they also use sound to reclaim 'acoustical agency' (Rice, 2016). However, such agency is also tied to the very system it seeks to escape as the singing, humming and music emanating from chain or prison gangs, and plantations, are not only sonic markers of difference, but mirror and reflect the rhythm and monotony of hard work, or the toil of capitalism. Such work songs kept colonised and exploited bodies productive by setting a productive work pace rhythm that ensured maximum productivity and profit, even when the pace was gruelling and unsustainable. Thus, they were an intrinsic and necessary component of capitalist accumulation processes (Franklin, 1979; Middlebrook, 2016). The relationship between forced labour and the back-breaking work integral to production, profit and capitalism was largely silenced, but instead justified on the grounds of reformation and teaching selfdiscipline through a regimented life (Smith 2014; Anderson 2019). This was reinforced by punishment, which also created its own aurality; sounds of punishment, pain, and suffering. 
The cracking of the whip, the choking induced by the hang-man's noose or the dull grinding sound of the treadmill, all denote the sound of suffering and the sound of punishment; sonic reminders of human cruelty. The haunting sounds of suffering and the subsequent trauma mean Guyana's prisons were - and still are - spaces in distress, which feel differently than spaces that have not experienced trauma (Coddington and Micieli-Voutsinas, 2017; Fiddler, 2019). Although the sounds of the contemporary prison may differ, they also resonate with the ghostly sounds of the past, as the prison becomes a crypt, built by violence, that contain the spectral sounds of coloniality and its sounds of suffering and control.

The bells at Mazaruni, New Amsterdam and Georgetown prisons were all installed during the colonial era. Although, bells were eventually phased out, and no longer haunt the prison structure, their use - like other sounds before that - is a ghostly reminder of unrelenting authority, power and control. The bell was a form of conditioning - of both staff and prisoners - that commanded disciplined movement (Hemsworth, 2015; Foucault 1977). In New Amsterdam and Mazaruni, and to a lesser extent Georgetown, the bell was used to take the tally, control movements, including the signalling of persons returning from both productive (e.g. breaking stones/rocks) and punitive (e.g. the treadmill) labour. A prison officer's whistle was also used to control movements and communicate with the prisoners in Guyana's prisons and 'each blast had its own significance' (Griffith, 1971: 5). Like the whistle, the bell was a sonic allay for guards - 'a technology that saved them energy and promoted the kind of efficiency sought in carceral environments' - and a kind of noise torment that emphasised a prisoner's 'lack of control over their own bodies' (Hemsworth, 2015: 24). A sonic form of conditioning that controlled docile colonised bodies, the free labour, which was integral to building the colonial infrastructure (including prisons like Mazaruni itself) and imperial economies. The bell was also used at the front gates to signal the arrival of a visitor; only then would the hatch in the prison gates be opened and the visitor welcomed in (Griffith, 1971). Not much has changed, the bell, buzzer and even the whistle are still used in prisons across the globe, including Guyana. The bell or the use of sound more generally links the contemporary prison to prisons of the past, and although bells have largely been replaced by more technologically advanced PA systems, all are a sonic documentation of punitive control and violence (Middlebrook, 2016).

After Independence the PA systems in Guyana's prisons were only located in New Amsterdam and Georgetown, as the electric supply to Mazaruni was intermittent and therefore not reliable enough to power a PA system. Across Guyana's prisons the PA system was mostly used for announcements, a one-way conversation, and as an electronic device barking commands and orders at prisoners and staff alike. However, like a lot of the prison estate in Guyana, once the PA system got old and broke, it was never updated or replaced. Now the sounds that dominate Guyana's prisons mostly come from the prisoners' radios and/or televisions, the constant hum of diesel generators, the sound of flies, lots of them, buzzing around constantly, and the sound of imposing metal entrance doors and other metal sounds from the prison infrastructure. Voices in the yard and coming from the buildings also travel on the air. Visitors walking through the jails will hear constant whistles and calls, which are turned up a level when women who are not staff are in the group. At night inmates speak of creaks, footsteps and the sound of keys turning in locks, yet when they turn to look there is no one there; just a haunting sound. Although, the soundscape of prison is ever changing and evolving as technology advances, sound permeates and joins the historical and contemporary prison, both of which are haunted with ghostly sounds from the past. Guyana's gaols are spatial crypts - a space in distress - that contain ghosts of the past. It is only by acknowledging Guyana's 
ghosts and the phantasm of trauma that we can begin to understand contemporary Guyana and Guyanese society, which includes their jails.

\section{Acknowledgements}

The authors would like to thank Kevin Pilgrim for his input on this paper, and Travis Linnemann for comments on an earlier draft.

\section{References}

Agamben, G. 2005. State of Exception (translated by Kevin Attell). Chicago: The University of Chicago Press.

Agamben, G. 1995. Homo Sacer: Sovereign Power and Bare Life. Stanford: Stanford University Press.

Anderson, C. 2012. Subaltern Lives: Biographies of Colonialism in the Indian Ocean World, 1790-1920. Cambridge: Cambridge University Press.

Anderson, C. 2016. Transnational Histories of Penal Transportation: Punishment, Labour and Governance in the British Imperial World, 1788-1939. Australian Historical Studies, 47 (3): 381-397.

Anderson, C. 2019. Convicts, Commodities, and Connections in British Asia and the Indian Ocean, 1789-1866. International Review of Social History, 64(S27): 205-227

Anderson, C., Ifill, M., Adams, E. and Moss, K. 2020. Guyana's Prisons: Colonial Histories of Post-Colonial Challenges. The Howard Journal of Crime and Justice Special Issue, 59 (3): 335-349.

Anderson, C., Moss, K. and Adams, E. 2020. Insanity and Imprisonment in colonial British Guiana. LIAS Working Paper 2020/4 . Leicester: Institute for Advanced Studies

Bundy, A.J.M. 1999. Selected Essays of Wilson Harris. London: Routledge.

Buntman, F. 2019. Prison and Law, Repression and Resistance: Colonialism and Beyond. The Journal of Imperial and Commonwealth History, 47(2): 213-246.

Carter, M.W. 1979. Poems of Resistance from Guyana. Guyana: Release Publishers.

Childs, D. 2015. Slaves of the State. London: University of Minnesota Press.

Clarke, K.M. 2010. The Politics of Faith and the Limits of Scientific Reason: Tracking the Anthropology of Human Rights and Religion. Religion and Society, 1 (1): 110-13.

Coddington, K. and Micieli-Voutsinas, J. 2017. On trauma, geography and mobility: Towards geographies of trauma. Emotion, Space and Society, 24: 52-56.

D'Harlingue, B. 2010. Spectres of the U.S. Prison Regime in M. del Pilar Blanco and E. Peeren (eds.) The Haunted Spaces of Everyday Culture: Popular Ghosts (pp. 133-146). New York: Continuum. 
De Ferrari, G. 2018. A Caribbean Hauntology: The Sensorial Art of Joscelyn Gardner and M. Nourbese Philip. Journal of Latin American Cultural Studies, 27 (3): 271-293

Derrida, J. 1994. Specters of Marx. London: Routledge.

Fiddler, M. 2019. Ghosts of Other Stories: A synthesis of hauntology, crime and space. Crime, Media, Culture, 15 (3): 463-477.

Foucault, M. 1977. Discipline and Punishment - The Birth of the Prison. London: Pantheon Books.

Franklin, H.B. 1979. Songs of an Imprisoned People. Multi-Ethnic Literature of the United States (MELUS), 6 (1): 6-22

Frosh, S. 2013. Hauntings: Psychoanalysis and Ghostly Transmissions. Basingstoke: Palgrave Macmillan.

Gampat, R. 2015. Guyana: From Slavery to the Present: Vol. 1 Health System. Guyana: Xlibris Corporation.

Gordon, A. 1997. Ghostly Matters. London: University of Minnesota Press.

Gregory, D. 2004. The Colonial Present. Oxford: Wiley-Blackwell.

Griffith, C.C. 1971. Within Four Walls. Guyana: Guyana Printers.

Grosfoguel, R. 2007. The Epistemic Decolonial Turn. Cultural Studies, 21 (2-3): 211-223.

Harris, W. 2006. The Ghost of Memory. London: Faber and Faber.

Harris, W. 1996. Jonestown. London: Faber and Faber.

Harris, W. 1993. The Carnival Trilogy. London: Faber and Faber.

Hemsworth, K. 2015. Carceral acoustemologies: Historical geographies of sound in a Canadian Prison in K. Morin and D. Moran (eds.) Historical Geographies (pp. 17-33). Oxon: Routledge.

Jewkes, Y. 2007. Captive Audience. Cullompton: Willan.

Linnemann, T. 2015. Capote's ghosts: Violence, media and the spectre of suspicion, British Journal of Criminology, 55 (3): 514-533.

Middlebrook, J.A. 2016. Songs in the Key of Incarceration: Prison Music as Sound, Theory, and Method. Qualitative Enquiry, 22 (10): 818-822.

Quijano, A. 2000. Coloniality of Power, Ethnocentrism, and Latin America. Nepantla, 1 (3): 533-580. 
Rice, T. 2016. Sounds inside: prison, prisoners and acoustical agency. Sound Studies, 2 (1): 620.

Robinson, C., 1981. Racial Capitalism in C.J. Robinson (ed.) Black Marxism: The Making of the Black Radical Tradition (pp. 9-28). London: Zed Press

Rodríguez, D. 2006. Forced Passages. London: University of Minnesota Press.

Said, E. 1978. Orientalism. New York: Pantheon Books.

Salah-Hana, V. 2015. Black Feminist Hauntology: Rememory the Ghosts of Abolition? Champ Pénal/Penal Field, XII: 1-33.

Sarsfield, R. and Bergman. M. 2017. Study of Inmates in Guyana. Guyana: Buenos Aires: Center for Latin American Studies on Crime and Violence, UNTREF, Inter-American Development Bank.

Schwab, G. 2010. Haunting Legacies. Chichester: Columbia University Press.

Smith, L. 2014. Insanity, Race and Colonialism: Managing Mental Disorder in the PostEmancipation British Caribbean, 1838-1914. Basingstoke: Palgrave Macmillan.

Stoler, L.A. 2008. Imperial Debris: Reflections on ruins and ruination. Cultural Anthropology, 23 (2): 191-219.

Stoler, L.A. 2006. Haunted by Empire. Durham: Duke University Press.

Sykes, G. 1958. Pains of Imprisonment. Oxford: Wiley.

Trouillot, M.R. 1995. Silencing the Past: Power and the Production of History. Boston: Beacon Press.

Wener, R.E. (2012) The Environmental Psychology of Prisons and Jails. Cambridge: Cambridge University Press. 